\title{
THE LIGHT REGIMEN AND GESTATION LENGTH IN THE MOUSE
}

\author{
D. G. PORTER* \\ Department of Physiology, Royal Veterinary College, London, N.W.1
}

(Received 20th November 1970, accepted 28th June 1971)

\begin{abstract}
Summary. The effect of altering the light regimen after copulation upon the duration of pregnancy in mice was investigated. It was found that mice bore young at a constant interval after copulation irrespective of the prevailing light conditions. No evidence was obtained that a light-dependent circadian mechanism determined the delivery time, although the possibility that such a mechanism might be established in the period immediately before mating was not ruled out by the present study. A significant negative correlation of litter size on gestation length was noted.
\end{abstract}

\section{INTRODUCTION}

There is evidence that the timing of the onset of labour in man and other species can be influenced by changes in the environment. For example, there have been several observations (Freak, 1962; Hafez, Sumption \& Jakway, 1962; Bleicher, 1962; Porter \& Schofield, 1966) which suggest that emotional disturbance at term can delay parturition. This has been supported by experimental studies in the mouse (Newton, Foshee \& Newton, 1966; Newton, Peeler \& Newton, 1968). Light, which has a profound influence on many aspects of reproduction (Amoroso \& Marshall, 1960), may be another environmental factor which can affect labour. A circadian rhythm, which might be photoperiod-dependent, in the frequency of births in man has been reported (King, 1956; Kaiser \& Halberg, 1962). Mitchell \& Yochim (1970) found that, if rats were subjected to prolonged illumination $(22 \mathrm{hr} / \mathrm{day})$ from the first day of pregnancy, gestation was prolonged by about $12 \mathrm{hr}$. The reason for this is obscure since exposure of the rats to the long day for either the pre- or postimplantation period alone failed to prolong gestation. Although reducing the light interval to only $2 \mathrm{hr}$ failed to alter gestation length, it revealed an apparent tendency for the animals to bear young in light, since $35 \%$ of them were delivered during the light period, i.e. during only $8.3 \%$ of the 24 -hr period. Mice, on the other hand, tend to bear young in darkness (Asdell, 1946). In a pilot study (D. G. Porter, unpublished work), all twenty-one mice under observation were delivered in the interval between 17.00 and 09.00 hours which included a dark period from 22.00 to 08.00 hours. Svorad \& Sáchová (1959) claimed that by reversing the lighting regimen after mating, the peak of deliveries in mice was

* Present address : Department of Anatomy, Harvard Medical School, Boston, Mass., U.S.A. 
shifted from the dark, 24.00 to 06.00 hours interval to the 12.00 to 18.00 hours interval (also in darkness) which suggests an approximate prolongation of pregnancy by 12 to $14 \mathrm{hr}$.

It seemed important to attempt to reproduce these results since a photoperiod-dependent mechanism of parturition would have significant bearing on present concepts of the hormonal initiation of labour.

\section{MATERIALS AND METHODS}

Albino mice of Tuck strain from a closed colony were housed in one or other of two similar rooms with differing light regimens. Lights in Room $\mathrm{C}$ were on from 12.00 to 04.00 hours and in Room D from 20.00 until the following 12.00 hours. The only light sources in the rooms were fluorescent lamps which produced an intensity of illumination of about 22 foot-candles at the level of the animal cages. The mice were allowed unrestricted access to a commercial diet. The cages were cleaned three times a week during the light interval in each room, and the temperature was maintained thermostatically in each room at approximately $75^{\circ} \mathrm{F}$.

Mice were mated in both rooms and at 12.00 hours on the day of finding a vaginal plug were either placed in a cage in the same room or transferred to the other room according to the following schedule.

Experiment 1 (mice reared in either room)

Mice mated in Room G (a) remaining in Room C

(b) transferred to Room D

Experiment 2 (mice reared in either room)

Mice mated in Room D (a) remaining in Room D

(b) transferred to Room $\mathbf{C}$

Experiment 3 (mice reared in either room)

Mice mated in Room D and placed under constant illumination (60 foot-candles) in separate room for 5 days before being returned to (a) Room D or (b) Room C

Experiment 4 (mice reared in Room C only)

Mice mated in Room G (a) remaining in Room C

(b) transferred to Room D

Experiment 5 (mice reared in Room $\mathrm{C}$ only)

Mice mated in Room D (a) remaining in Room D

(b) transferred to Room G

All transfers were carried out at 12.00 hours so that the mice experienced a long dark (16-hr) or long light $(20-\mathrm{hr})$ period immediately after mating. Wherever possible, alternate mice were transferred from the mating room to the experimental room. The animals in Exp. 3 were transferred to constant light on Day 5 , in order to avoid interfering with normal implantation, and were returned to their designated rooms on Day 10.

In order to determine the times of delivery, the cages of all animals in both rooms were examined at four predetermined times each day from Day 18 of 
pregnancy until delivery. The times selected were $09.00,12.00,17.00$ and 22.00 hours. The 09.00 - and 17.00-hour examinations entailed a brief interruption of the dark period in Rooms $\mathrm{C}$ and $\mathrm{D}$, respectively, although room lights were not switched on and examinations were conducted in the light issuing through the mouse-room door from an ante-room. Since the interruptions occurred at the same point in the dark period for both groups, it was assumed that no bias was introduced. The duration of pregnancy was calculated after making the following arbitrary assumptions: (i) that mating occurred at the midpoint of the dark period after which a copulatory plug was found and (ii) that delivery occurred at the inspection time at which a litter was found. (Delivery was recorded as the time at which either a litter was found or the mouse was found to be in labour.) Although this method of estimating slightly exaggerates gestation length, and although the unequal intervals between inspections introduces distortion, these effects are the same in both groups and therefore should be free from bias.

\section{RESULTS}

The results of the experiments are shown in Table 1. Analysis of variance (Snedecor, 1956) of the data showed that there was no significant difference in the mean duration of pregnancy among the ten experimental groups. Textfigure 1 shows the distribution of deliveries in relation to the light regimens of the experimental rooms.

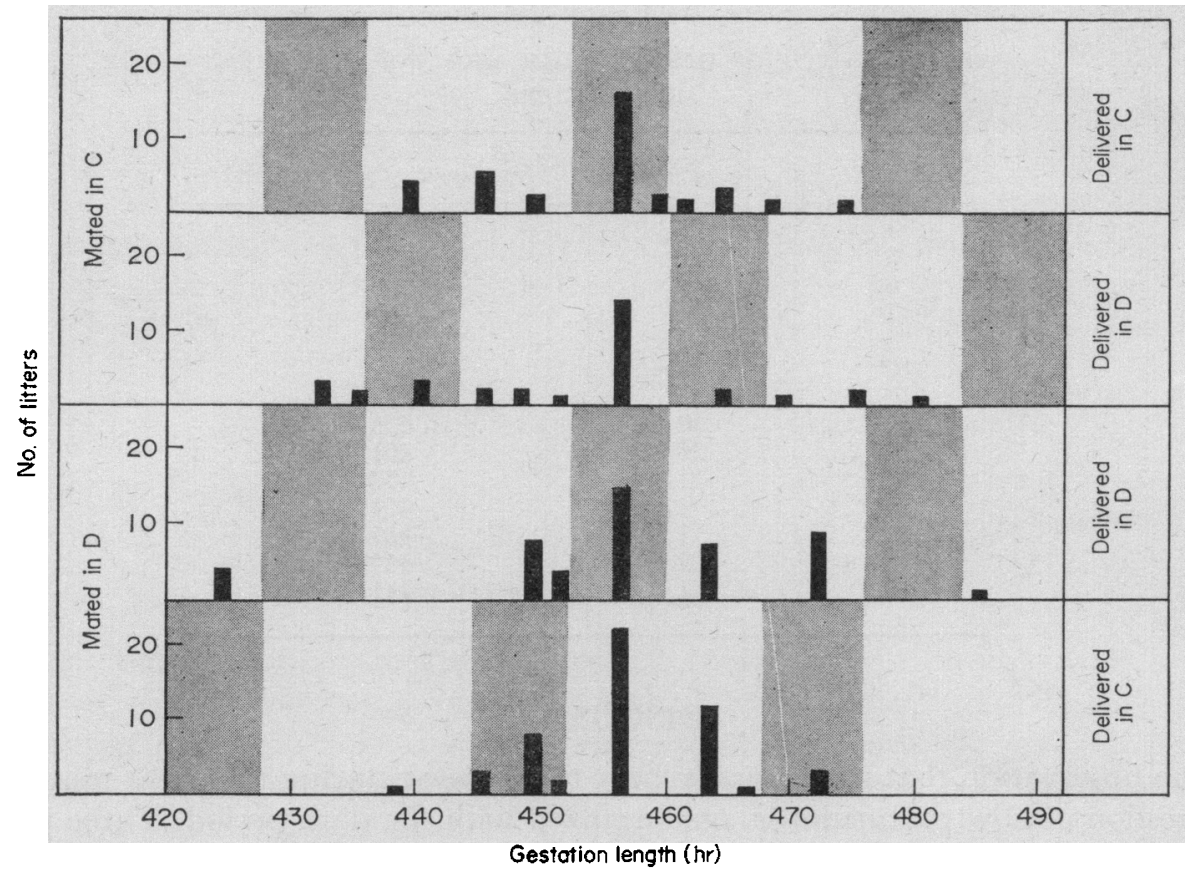

TEXT-FIG. 1. Histogram to show incidence of deliveries in Rooms $\mathbf{C}$ and $\mathbf{D}$ in relation to the light regimen and the duration of pregnancy (all experimental groups combined). Vertical black bars : no. of litters; stippled areas: dark periods. 
The mean litter size for each experimental group is shown in Table 1. No significant difference existed between the mean litter sizes among the groups (analysis of variance). The mean litter size in relation to the duration of pregnancy for all groups combined, is shown in Table 2. There was a statistically significant $(P<0.005)$ negative regression of litter size $(Y)$ on duration of pregnancy $(\mathrm{X})$ (regression equation: $\mathrm{Y}=35.7-0.056 \mathrm{X}$ ).

TABLE 1

GESTATION LENGTHS, AND LITTER SIZES OF MICE UNDER DIFFERENT LIGHT REGIMENS

\begin{tabular}{|c|c|c|c|c|c|c|c|}
\hline Group & $\begin{array}{l}\text { Animals } \\
\text { reared } \\
\text { in room }\end{array}$ & $\begin{array}{l}\text { No. of } \\
\text { litters }\end{array}$ & $\begin{array}{l}\text { Animals } \\
\text { mated } \\
\text { in room }\end{array}$ & $\begin{array}{c}\text { Constant } \\
\text { light } \\
\text { Day } 5 \text { to } 10^{*}\end{array}$ & $\begin{array}{c}\text { Animals } \\
\text { delivered } \\
\text { in room }\end{array}$ & $\begin{array}{l}\text { Duration of } \\
\text { pregnancy } \\
(h r \pm S . E .)\end{array}$ & $\begin{array}{l}\text { Mean } \\
\text { litter } \\
\text { size }\end{array}$ \\
\hline $\begin{array}{r}1 \mathrm{a} \\
\mathrm{b}\end{array}$ & $\begin{array}{l}\text { C or } \mathrm{D} \\
\mathrm{C} \text { or } \mathrm{D}\end{array}$ & $\begin{array}{l}25 \\
23\end{array}$ & $\begin{array}{l}\text { C } \\
\text { C }\end{array}$ & - & $\begin{array}{l}\text { C } \\
\text { D }\end{array}$ & $\begin{array}{l}456 \pm 1 \cdot 8 \\
454 \pm 2 \cdot 6\end{array}$ & $\begin{array}{l}10 \cdot 8 \\
11 \cdot 1\end{array}$ \\
\hline$\underset{b}{2 a}$ & $\begin{array}{l}\text { C or } D \\
\text { C or } D\end{array}$ & $\begin{array}{l}15 \\
23\end{array}$ & $\begin{array}{l}\text { D } \\
\text { D }\end{array}$ & - & $\begin{array}{l}\text { D } \\
\text { C }\end{array}$ & $\begin{array}{l}460 \pm 3 \cdot 2 \\
458 \pm 1 \cdot 3\end{array}$ & $\begin{array}{r}9 \cdot 3 \\
10 \cdot 4\end{array}$ \\
\hline $\begin{array}{r}3 a \\
b\end{array}$ & $\begin{array}{l}\text { C or D } \\
\text { C or } D\end{array}$ & $\begin{array}{l}24 \\
21\end{array}$ & $\begin{array}{l}\mathrm{D} \\
\mathrm{D}\end{array}$ & $\dot{t}$ & $\begin{array}{l}\text { D } \\
\text { C }\end{array}$ & $\begin{array}{l}455 \pm 2 \cdot 3 \\
457 \pm 1 \cdot 4\end{array}$ & $\begin{array}{l}10.2 \\
10.2\end{array}$ \\
\hline $\begin{array}{r}4 a \\
b\end{array}$ & $\begin{array}{l}\text { C only } \\
\text { C only }\end{array}$ & $\begin{array}{l}10 \\
10\end{array}$ & $\begin{array}{l}\mathbf{C} \\
\mathbf{C}\end{array}$ & - & $\begin{array}{l}\text { C } \\
\text { D }\end{array}$ & $\begin{array}{l}453 \pm 2 \cdot 5 \\
452 \pm 3 \cdot 8\end{array}$ & $\begin{array}{r}9 \cdot 7 \\
11 \cdot 0\end{array}$ \\
\hline $\begin{array}{r}5 a \\
b\end{array}$ & $\begin{array}{l}\text { C only } \\
\text { C only }\end{array}$ & $\begin{array}{l}9 \\
7\end{array}$ & $\begin{array}{l}\mathrm{D} \\
\mathrm{D}\end{array}$ & - & D & $\begin{array}{l}459 \pm 5 \cdot 2 \\
455 \pm 1.8\end{array}$ & $\begin{array}{r}9 \cdot 6 \\
10 \cdot 4\end{array}$ \\
\hline
\end{tabular}

* Day 1 = Day of finding vaginal plug.

TABLE 2

MEAN LENGTH OF GESTATION IN MICE FOR DIFFERENT LITTER SIZES

\begin{tabular}{c|c|c}
\hline Litter size & No. of litters & Mean length of gestation $(\mathrm{hr})$ \\
\cline { 2 - 3 } & 1 & 473 \\
5 & 1 & 457 \\
6 & 6 & 458 \\
7 & 4 & 462 \\
8 & 10 & 462 \\
9 & 24 & 457 \\
10 & 23 & 454 \\
11 & 30 & 455 \\
12 & 26 & 451 \\
13 & 11 & 452 \\
14 & 7 & 451 \\
15 & 1 & 457 \\
16 & 2 & 444 \\
17 & 1 & 441 \\
\hline
\end{tabular}

\section{DISCUSSION}

The observation that mice usually bear their young during the night raises the question of how parturition is synchronized with the dark period. Three probable mechanisms might be considered. The female mouse may be capable of 'consciously' influencing, through a form of nervous control, the time of delivery of its litter within reasonable limits, or it is possible that the onset of labour is 
determined by a mechanism which is based upon a photoperiod-dependent circadian rhythm. A further possibility is simply that the peak of the distribution of the mating (or possibly implantation)-delivery intervals of a population of mice coincides with a naturally recurring dark period.

The findings of the present study indicate that normal nocturnal delivery is not achieved by the ability of the mouse to regulate its own parturition. There was no evidence of a delay in labour among mice bred in one room which were delivered in another (Text-fig. 1). Thus, the peak delivery time was $457 \mathrm{hr}$ after mating, irrespective of the prevailing light regimen. This finding also argues against the underlying mechanism being based upon a photoperiod-dependent circadian rhythm. However, it could be argued that the rhythm is established by the light conditions prevailing before mating. An attempt to interrupt such a rhythm by subjecting the mice to 5 days of constant light was unsuccessful.

The use of animals reared in one room only (Room G) confirmed that, if a circadian rhythm was involved, it was established before copulation but showed further that if such a rhythm was established during rearing it was not permanent. Thus, mice reared to sexual maturity in Room C but mated in Room D were delivered according to the pattern of animals mated in Room D, whereas those reared and mated in $\mathrm{C}$ were delivered according to the pattern of animals mated in $\mathrm{C}$. The conclusion to be drawn from these findings is that if a circadian rhythm is involved, it is established by the light regimen in which mating takes place and cannot be altered by subsequent changes in the photoperiod. Mice which were reared from birth to sexual maturity (a period of 75 days) in Room C, mated within 12.6 days (on average) of being placed with males in Room D. The fact that these same mice, on being returned to Room $\mathrm{C}$ for the remainder of pregnancy (19 days) were delivered at the same time as all other mice mated in $\mathrm{D}$, argues against the existence of a photoperiod-dependent circadian rhythm of parturition.

Thus, the present data suggest that, in the majority of mice, parturition occurs at a relatively constant interval after mating (or implantation), the end of which happens to coincide with a naturally occurring dark period. Such a mechanism would also explain the apparent 'tendency' of rats to deliver in a very brief light period, observed by Mitchell \& Yochim (1970). The 2-hr light period of their experiments coincides with the peak delivery time of their control rats kept under a 14-hr light regimen, so that it is not surprising that a high percentage of animals were delivered in the short light interval.

The results of the present experiments are at variance with those of Svorad \& Sáchová (1959) who found that inverting the light regimen during pregnancy, caused a shift in the peak period of births from the 24.00 to 06.00 hour interval (dark) to the 12.00 to 18.00 hour interval (dark). The reason for the marked difference between their results and those of the present study is obscure.

The finding of a significant negative regression of litter size on duration of pregnancy (Table 2) is consistent with the similar findings of Biggers, Curnow, Finn \& McLaren (1963) in the mouse and Goy, Hoar \& Young (1957) in the guinea-pig. 


\section{ACKNOWLEDGMENTS}

The author is indebted to Mrs Cynthia Doughty for supervision of the mouse breeding and deliveries, and to $\mathrm{Mr} \mathrm{J}$. Lewin for care of the animal colony and for the evening inspections.

\section{REFERENCES}

Amoroso, E. G. \& Marshall, F. H. A. (1960) External factors in sexual periodicity. In: Marshall's Physiology of Reproduction, Vol. 1, Ch. 13. Ed. A. S. Parkes. Longmans Green, London.

Asdell, S. A. (1946) Patterns of mammalian reproduction. Comstock Publishing Co., New York.

Biggers, J. D., Gurnow, R. N., Finn, C. A. \& MaLaren, A. (1963) Regulation of the gestation period in mice. 7. Reprod. Fert. 6, 125.

Bleicher, N. (1962) Behaviour of the bitch during parturition. F. Am. vet. med. Ass. 140, 1076.

FreAK, M. J. (1962) Abnormal conditions associated with pregnancy and parturition in the bitch. Vet. Rec. 74, 1323.

Goy, R. W., Hoar, R. M. \& Young, W. C. (1957) Length of gestation in the guinea pig with data on the frequency and time of abortion and stillbirth. Anat. Rec. 128, 747.

Hafez, E. S. E., Sumption, L. J. \& Jakway, J. S. (1962) The behaviour of swine. In: The Behaviour of Domestic Animals. Ed. E. S. E. Hafez. Williams \& Wilkins, Baltimore.

Katser, I. H. \& Halberg, F. (1962) Circadian periodic aspects of birth. Ann. N. Y. Acad. Sci. 98, 1056.

KING, P. D. L. (1956) Increased frequency of births in the morning hours. Science, N. T. $123,985$.

Mrтchell, J. A. \& Yоснім, J. M. (1970) Influence of environmental lighting on duration of pregnancy in the rat. Endocrinology, 87, 472.

Newton, N., Foshee, D. \& Newton, M. (1966) Experimental inhibition of labor through environmental disturbance. Obstet. Gynec., $\mathcal{N} . \Upsilon .27,371$.

Newton, N., Peeler, D. \& Newton, M. (1968) Effect of disturbance on labor (an experiment with 100 mice with dated pregnancies). Am. F. Obstet. Gynec. 101, 1096.

Porter, D. G. \& Schofield, B. M. (1966) Intra-uterine pressure changes during pregnancy and parturition in rabbits. F. Endocr. 36, 291.

SNEdeCOR, G. W. (1956) Statistical methods, 5th edn. Iowa State College Press.

Svorad, D. \& SÁchová, V. (1959) Periodicity of the commencement of birth in mice and the influence of light. Physiologia bohemoslov. 8, 439. 